\title{
The Impact of Legislative Framework Conditions on the Development of Stem Cell Technology: Assessment of National Innovation Systems
}

\author{
By ISABELLE HUYS, MARIETTE DU PLESSIS, CHRISTOPHE WAER, \\ GEERTRUI VAN OVERWALLE, and BART VAN LOOY
}

\begin{abstract}
$\mathbf{S}_{\mathrm{a}}^{\mathrm{r}}$ TEM CELLS have the potential to launch a new area of medicine, curing deadly diseases with custom-made tissues and organs. But science and technology may have to take note of regulatory developments, which might impact if, how, and where that hope will be realized. Until now, no data have been available on the influence of national human stem cell research legislation on the technological activity in the field of stem cells. In this contribution, we assess whether legislative framework conditions affect technological activity in this field. Stem cell patent activity (US Patent and Trademark Office [USPTO]/European Patent Office [EPO]) and legislative framework conditions with respect to human stem cell research have been identified and characterized for the period 1997-2003 for 23 countries. For these countries, differences in human stem cell legislation coincide with differences in technological productivity. Where obtaining human stem cells from supernumerary embryos is permitted, higher levels of technological productivity for all types of stem cell research are observed. A more permissive legislative approach to human therapeutic cloning coincides with greater emphasis on embryonic stem cell development activities in general. These findings suggest that technology trajectories are modulated by (national) legislative frameworks.
\end{abstract}

\section{INTRODUCTION}

Stem cells are undifferentiated primary cells, found in all vertebrates and playing important roles in nor-

Prof. Dr. Isabelle Huys is at the Faculty of Pharmaceutical Sciences and Centre for Intellectual Property Rights, Katholieke Universiteit Leuven (Belgium); Mariette Du Plessis is at the Centre for R\&D Monitoring (ECOOM), Katholieke Universiteit Leuven, Dekenstraat 2, 3000 Leuven, Belgium; Christophe Waer and Prof. Bart Van Looy are at the Department of Managerial Economics, Innovation, and Strategy, Faculty of Business and Economics, Katholieke Universiteit Leuven, Naamsestraat 69, 3000 Leuven, Belgium, Prof. Dr. Van Looy also is affiliated with the Centre for R\&D Monitoring (ECOOM) and IGS, University of Twente (The Netherlands); Prof. Dr. Geertrui Van Overwalle is at the Centre for Intellectual Property Rights, Faculty of Law, Katholieke Universiteit Leuven (Belgium) and at the Tilburg Institute for Law, Technology, and Society (The Netherlands). Correspondence may be addressed to Isabelle Huys, e-mail: Isabelle.Huys@law.kuleuven.be, fax: + 3216 323730 or Bart Van Looy, email: Bart.Vanlooy@econ.kuleuven .be, fax: + 3216326732 . mal development and regeneration or repair of tissues. Embryonic stem cells (ESCs) are of particular interest because of their ability to divide into identical cells or to differentiate or specialize into many types of body cells. In contrast, adult stem cells have less replication capacity. However, human ESCs (hESC) are isolated from early-stage human embryos, triggering ethical debates around the world.

As a consequence, no area of biological $R \& D$ has been governed by such an unusual number of diverse and continually evolving policies as hESCs. At an international level (United Nations/UNESCO), various relevant non-binding declarations, principles, and ethical guidelines have been adopted. Different nations have installed legislation either restricting or permitting (or even neglecting) this type of research. ${ }^{1}$ In

\footnotetext{
${ }^{1}$ Dhar D, His-En Ho J. Stem cell research policies around the world. Yale J Biol Med 2009;82:113-5; Van Overwalle G. Study on the patenting of inventions related to human stem cell research, European Communities, Luxembourg, 2002.
} 
Europe, whether and how the use of stem cells is allowed depends on a Member State's position on the status of the human embryo. The situation becomes more complicated with respect to the availability of funding for stem cell research. In Europe, until 2003, no funding could be obtained from the European Framework program for research intended to create new hESC lines, except for projects involving banked hESC cultures. After 2004, EU funding became available on a project-byproject basis. Under the current framework program (FP7), three fields of stem cell research are excluded: (1) research aimed at human cloning for reproductive purposes; (2) activities intended to modify the genetic heritage of human beings that could make such changes heritable; and (3) research intended to create human embryos solely for the purpose of research or stem cell procurement. In earlier years in the US, hESC research did not receive federal funding because of the Dickey amendment ( $\$ 128$ of Publ L 104-99). From 2000 onward, the National Institutes of Health (NIH) allowed funding of pluripotent hESC research. However, on August 9, 2001, former President George W. Bush restricted funding for hESC research to the 22 cell lines that existed at that time. It was only in March 2009 that a US President's executive order lifted the ban on US federal funding for hECS research. That change is now under legal challenge.

Aside from the scientific challenges stem cell researchers face, the variety of regulatory frameworks surrounding hESCs creates ethical, economic, political, and financial uncertainties and might force researchers to focus more on adult stem cells. The current study empirically analyzes whether national research legislation on human stem cells has an impact on the furtherance of stem cell technology. Previous studies focused mainly on the global patent landscape of stem cell technology $\mathrm{y}^{2}$ and explored the influence of human stem cell research legislation on the productivity of a country in terms of the number or quality of peer-reviewed research publications ${ }^{3}$ and on the mobility of stem cell researchers. ${ }^{4}$ These studies indicated that although the US is clearly leading in the field-in terms of absolute numbers of publications ${ }^{5}$ - differences in legislation seem to affect the choices of scientists in terms of topics and hence location. ${ }^{6}$ Both Levine ${ }^{4}$ and Owen-Smith and McCormick ${ }^{7}$ suggested that the restrictive funding conditions installed in the US in 2001 might result in American scientists lagging behind in the field of embryonic stem cell research.

Complementary to these studies, we focus on differences in national legal frameworks with respect to stem cell research and their impact on the technological activity of countries. Stated otherwise, to contrib- ute to the complex societal debate surrounding human stem cell research, this article analyzes empirically whether different legislative frameworks actually coincide with differences in technological activity in human stem cell research.

\section{METHODOLOGY}

The study analyzes the relation between the amount of technological activity, measured by patent indicators, and legislative frameworks pertaining to human stem cell research from 1997-2003. The unit of anal$y s i s$ is at the level of national innovation systems, ${ }^{8}$ which seems entirely appropriate, given that most legislative arrangements coincide with national boundaries. ${ }^{9}$

\section{Identifying technology activity in the field of stem cells}

As the analysis of patents is considered one of the most reliable methods for quantifying the technological output of innovation systems, ${ }^{10}$ patent documents from the USPTO and EPO pertaining to stem cells were identified and analyzed for the period 19972003. All stem cell activity has been taken into consideration, including developments that pertain to nonhuman stem cells, as research efforts in this area are considered relevant and instrumental for human stem cell $R \& D$ activities.

Stem-cell-related patents were identified by applying a search key developed and validated in con-

\footnotetext{
${ }^{2}$ Bergman K, Graff G. Collaborative IP management for stem cell research and development. PIPRA Report 2007.

${ }^{3}$ Winston RML. Does government regulation inhibit embryonic stem cell research and can it be effective? Cell Stem Cell 2007;1:27-34.

${ }^{4}$ Levine AD. Research policy and the mobility of US stem cell scientists. Nat Biotechnol 2006;24(7).

${ }^{5}$ Winston, op. cit. $\mathrm{n} 3$.

${ }^{6}$ Levine, op. cit. $\mathrm{n} 4$.

${ }^{7}$ Owen-Smith J, McCormick J. An international gap in human ES cell research. Nat Biotechnol 2006;24:391-2.

${ }^{8}$ Freeman C. Technology Policy and Economic Performance. London: Pinter Publishers, 1987; Lundvall BA. National Systems of Innovation: Towards a Theory of Innovation and Interactive Learning. London: Pinter Publishers, 1992; Nelson RR, ed. National Innovation Systems: A Comparative Analysis. New York: Oxford University Press, 1993.

${ }^{9}$ Certain US states are adopting legislation mainly prohibiting reproductive cloning; more differentiated initiatives occurred only after 2003 and are not included in the current analysis.

${ }^{10}$ Griliches Z. Patent statistics as economic indicators: a survey, J Econ Lit 1990;28:1661-707; Grupp H, Schmoch U. Patent statistics in the age of globalisation: new legal procedures, new analytical methods, new economic interpretation? Res Pol'y 1999;28:377-96.
} 
junction with domain experts ${ }^{11}$ (for full details, see Glänzel et $\left.\mathrm{al}^{12}\right) .{ }^{13}$ Data were extracted in mid-2005. As applications are published only after 18 months, 2003 is the most recent year for which complete data are available. For the EPO, both patent applications and grants for the years 1997-2003 have been included. Although granted US patents were analyzed, USPTO applications have not been included, as the USPTO publishes application information only from 2001 onward; in addition, the information published on USPTO applications contains less applicant address information, preventing an exhaustive allocation to different countries.

In order to analyze the differential effects on embryonic and adult stem cell activity, these patent documents have been further classified into four categories: ${ }^{14}$ (1) embryonic cells; (2) adult stem cells; (3) patents where no distinction is made between adult and embryonic stem cells in the title or abstract; and (4) techniques for culturing stem cells (e.g., using different feeder layers, growth factors, and hormones). In a subsequent step, patent documents have been assigned to countries on the basis of the nationality of the applicants, as applicants are subject to national legislative framework conditions. In the case of applications involving applicants of different nationalities, full counts have been applied. ${ }^{15}$

In total, we observed patent activity in the field of stem cell technology for 27 countries. Excluded from our analysis were outliers $(n=4)$ : countries for which the dependent variable (amount of patent activity/capita) diverges more than 3 standard deviations from the mean, resulting either from low numbers of patent (application) counts (Uruguay and Czech Republic) or a small number of inhabitants (e.g., Luxemburg, The Netherlands Antilles). ${ }^{16}$

\section{Assessing legislative framework conditions}

For the countries in which significant technological activity in the field of stem cell technology has been identified, a content analysis of legislative framework conditions on human stem cell research has been performed. Legislative documents from a range of sources have been used. ${ }^{17}$ After expert validation, the following four dimensions have been used to characterize human stem cell legislation on a national level according to which activities were allowed at the time: (1) R\&D aimed at human reproductive cloning; (2) R\&D aimed at human therapeutic cloning; (3) procurement of human stem cells from supernumerary embryos for R\&D; and (4) use of human adult stem cells for R\&D.

Each country obtained a score on these four dimensions. Scores of 0 and 1 were given if legislation explicitly prohibited (0) or allowed (1) these activities. In cases where no legislation pertaining to human stem cell research existed or where legislation was vague or ambiguous in terms of permitting human stem cell research, a score of 2 was applied. Countries were able to obtain different values for different years if pertinent legislative changes occurred. After characterizing all countries for which stem cell patent data have been collected, two dimensions were dropped from the analysis because of lack of variance: all countries under study explicitly banned research activities pertaining to human reproductive cloning (1), whereas all of them permitted the use of human adult stem cells for research and development (4).

\section{Modeling the relation between legislative framework and technological activity}

In order to assess the relation between human stem cell legislative frameworks and technological activity in the field of stem cells in general, we opted for an analysis of (co)variance (ANCOVA). Technological productivity-i.e., the number of patents on stem

${ }^{11}$ Identified patents have been analyzed in terms of relevance by two experts (B Sarkadi, Head of the Department of Cell Metabolism at the National Institute of Haematology and Immunology, Budapest, and International Research Scholar of the Howard Hughes Medical Institute, USA, and C Verfaillie, Director of the Stem Cell Institute, University of Minnesota and Katholieke Universiteit Leuven).

12 Glänzel W, Verbeek A, Du Plessis M, Van Looy B, Magerman T, Thijs B, Schlemmer B, Debackere K, Veugelers R. Stem cells: analysis of an emerging domain of scientific and technological endeavour. Report by Steunpunt O\&O Statistieken. Leuven, Belgium: Katholieke Universiteit Leuven, 2004.

${ }^{13}$ This search key implied a combination of terms (e.g., *stem cell*; * ES cell* or *.ES cell* or -ES cell*; * progenitor cell* or *hematopoi* cell*).

${ }^{14}$ A semiautomated procedure was used to classify the patents. If only the words "embryo" or "embryonic" were observed in the title or abstract, the work was classified as category 1 . For category 2, the terms "adult" or "progenitor cell" were used, excluding the terms "embryo/embryonic." Patent documents that combined both sets of keywords were classified as category 3 . The remaining patents were grouped in category 4 . The outcomes of this technique were validated by experts.

${ }^{15}$ Applying a fractional count logic yields results similar to the ones reported in this paper.

${ }^{16}$ At the same time, it can be noted that results obtained without excluding outliers are completely in line with the findings reported in Table 4 below.

${ }^{17}$ European Commission, Directorate General-Research: Survey on opinions from National Ethics Committees or similar bodies, public debate, and national legislation in relation to human embryonic stem cell research and use. Volume I: EU Member States, July 2004; available at www.europa.eu.int/ comm/research/biosociety/bioethics/documents_en.htm; Volume II: Countries associated to FP6 and Third Countries, July 2004; available at www.europa.eu.int/comm/research/ biosociety/bioethics/documents_en.htm; Database of Global Policies on Human Cloning and Germ-Line Engineering; available at www.glphr.org/genetic/genetic.htm or www.mbbnet .umn.edu/scmap.html 
cells per country divided by population-acts as the dependent variable. We applied a logarithmic transformation in order to obtain a normal distribution. In addition to the two legislative dimensions (obtaining human stem cells from supernumerary embryos and $\mathrm{R} \& \mathrm{D}$ on human therapeutic cloning), the patent system (USPTO/EPO), type of human stem cell research, and status of the patent (granted/application) act as independent, categorical, variables. The R\&D expenditures per capita have been included as a covariate in order to control for differences between countries in terms of overall R\&D intensity (source: Eurostat and OECD).$^{18}$ It can be noted that R\&D expenditures in the field of biotechnology-or even stem cellswould be a better control variable to assess the specific impact of legislation. Because such detailed harmonized statistics are not available for the majority of countries under study, overall yearly $R \& D$ expenditures (divided by GDP) have been used. Given the specific focus of this contribution, interaction effects between the legal variables as well as between the legal variables and type of stem cell activity are included. ${ }^{19}$

\section{RESULTS}

\section{Technological activity}

Identification. In total, 1571 US patents, European patents, and European patent applications related to stem cell technology were identified for the period 1997-2003 (Table 1). For the US, 762 patents were granted, whereas in Europe, as of April 2005, 48 patents were granted and 761 applications were still pending.

Classification. In Europe as well as in the US, most of the relevant documents (patents and patent applications) relate to adult stem cells (Table 2). Likewise, most granted European patents pertain to adult stem cells. Although in Europe, compared with the US, a higher number of patent documents refer to embryonic stem cells, these are mainly applications.

Assignment of patents to countries. In total, 27 nationalities were identified for the assignees in the dataset compiled with the search key outlined. Significant technological activity was identified for 23 countries, which were withheld for further analysis. A few outli-

Table 1. Number of Stem Cell Patents Identified IN USPTO AND EPO Patent Systems For 1997-2003

\begin{tabular}{lcc}
\hline Period & Patent office & $\begin{array}{c}\text { Number of granted/pending } \\
\text { stem cell patents }\end{array}$ \\
\hline $1997-2003$ & USPTO & $\begin{array}{l}762 \text { granted } \\
\text { 1997-2003 applications (of which 48 } \\
\text { had been granted } \\
\text { as of April 2005) }\end{array}$ \\
& EPO & \\
\hline
\end{tabular}

Table 2. Number of Patents and Patent Applications in Each of Four Stem Cell Categories for 1997-2003

\begin{tabular}{lcc}
\hline Category of stem cells & EPO & USPTO \\
\hline Embryonic $^{\mathrm{a}}$ & 140 & 85 \\
Adult $^{\mathrm{b}}$ & 401 & 420 \\
Stem cells $^{\mathrm{c}}$ & 118 & 137 \\
Stem cell-related technology $^{\mathrm{d}}$ & 150 & 120 \\
Total & 809 & 762 \\
\hline
\end{tabular}

${ }^{\mathrm{a}}$ Mention of the isolation or use of embryonic stem cells in the title or abstract.

${ }^{\mathrm{b}}$ Mention of the isolation or use of adult stem cells or progenitor cells in the title or abstract.

"Mention of the words "stem cell" in the title or abstract with no distinction made between adult and embryonic cells.

${ }^{\mathrm{d}}$ For example, techniques for culturing cells; e.g., different feeder layers, growth factors, and hormones.

ers $(n=4)$ have been excluded from the analysis (see supra). The countries under study are Austria, Australia, Belgium, Canada, China, Czech Republic, Denmark, France, Germany, India, Israel, Italy, Japan, Norway, Republic of Korea, Singapore, Spain, Sweden, Switzerland, Taiwan, The Netherlands, United Kingdom, and United States. In total, 1394 patents and patent applications were held for further analysis.

\section{Legislative framework conditions}

Out of the 23 countries under study up to 2004,10 did not provide any clear national legislation on human stem cell research. Of the remaining countries, seven banned obtaining hESCs from supernumerary embryos at the beginning of our observations. Within the observation period, eight countries changed their legislation to allow use of hESCs from supernumerary embryos (Table 3). Three countries (Germany, Austria, France) allow importation of hESC lines under strict conditions. Eight countries started to allow research in the field of therapeutic cloning within the observed time. In the EU, only the UK and Belgium allow cloning of human stem cells for therapeutic or research purposes. Outside Europe, countries with permissive laws include India (from 2002), Japan (from 2001), China (from 2004), Singapore (from 2004), South Korea (from 2004), and Israel (from 2002).

\footnotetext{
${ }^{18}$ An alternative approach to accommodate differences in R\&D expenditures consists of dividing the observed patent activity by $R \& D$ expenditures and uses the obtained measure as a dependent variable. In Appendix 1, the results obtained when adopting this approach can be found. As one can notice, the results are in line with the findings reported in Table 4 below.

${ }^{19}$ A full factorial model, including all interaction effects, yields results similar to the ones reported here.
} 
Table 3. Number of Countries in Each Category of Legislation on Stem Cell Research

\begin{tabular}{|c|c|c|c|c|c|c|}
\hline \multirow[b]{2}{*}{ Legislation } & \multicolumn{2}{|c|}{ Not allowed } & \multicolumn{2}{|c|}{ Allowed } & \multicolumn{2}{|c|}{ Vaguelambiguous legislation } \\
\hline & Pre 2000 & Post 2004 & Pre 2000 & Post 2004 & Pre 2000 & Post 2004 \\
\hline $\begin{array}{l}\text { Obtaining stem cells from } \\
\text { supernumerary embryos }\end{array}$ & 7 & 2 & 6 & 18 & 10 & 3 \\
\hline $\mathrm{R} \& \mathrm{D}$ on therapeutic cloning & 20 & 12 & 0 & 8 & 3 & 3 \\
\hline
\end{tabular}

Table 4. AnCova Results: Technological Productivity (Log Stem Cell Patents per Capita) as DePendent Variable

\begin{tabular}{|c|c|c|c|c|c|}
\hline Source & $\begin{array}{l}\text { Type III sum } \\
\text { of squares }\end{array}$ & $d f$ & $\begin{array}{l}\text { Mean } \\
\text { square }\end{array}$ & $F$ & $P$ value \\
\hline Corrected model & $35.825^{\mathrm{a}}$ & 23 & 1.558 & 8.804 & 0.000 \\
\hline Intercept & 5.429 & 1 & 5.429 & 30.683 & 0.000 \\
\hline Patent system (EPO/USPTO) & 1.722 & 1 & 1.722 & 9.735 & 0.002 \\
\hline Issued (Y/N) & 5.790 & 1 & 5.790 & 32.724 & 0.000 \\
\hline Type of stem cells & 1.675 & 3 & 0.558 & 3.155 & 0.025 \\
\hline Obtaining stem cells from supernumerary embryos allowed & 5.666 & 2 & 2.833 & 16.012 & 0.000 \\
\hline $\mathrm{R} \& \mathrm{D}$ on therapeutic cloning allowed & 6.614 & 2 & 3.307 & 18.691 & 0.000 \\
\hline $\mathrm{R} \& \mathrm{D}$ intensity & 1.003 & 1 & 1.003 & 5.667 & 0.018 \\
\hline $\begin{array}{l}\text { R\&D on therapeutic cloning allowed* obtaining stem } \\
\text { cells from supernumerary embryos allowed }\end{array}$ & 0.426 & 1 & 0.426 & 2.409 & 0.122 \\
\hline Type of stem cells* R\&D on therapeutic cloning allowed & 1.837 & 6 & 0.306 & 1.730 & 0.114 \\
\hline $\begin{array}{l}\text { Type of stem cells* obtaining stem cells from } \\
\text { supernumerary embryos allowed }\end{array}$ & 0.683 & 6 & 0.114 & 0.644 & 0.695 \\
\hline Error & 48.478 & 274 & 0.177 & & \\
\hline Total & 139.92 & 298 & & & \\
\hline Corrected total & 84.303 & 297 & & & \\
\hline
\end{tabular}

$\mathrm{R}^{2}=0.425$ (adjusted $\mathrm{R}^{2}=0.377$ ).

\section{Relation between legislative framework conditions and technological activity}

Table 4 provides an overview of the results obtained by ANCOVA. As mentioned, several control variables have been introduced into the model. The findings pertaining to these control variables will be discussed first.

As becomes apparent when inspecting Table 2, most patent activity is observed for adult stem cells. The observed differences turn out to be statistically significant when looking at normalized patent data as well $(\mathrm{P}<0.05)$. Productivity of countries was significantly higher within the EPO system than the USPTO system $(\mathrm{p}=0.001)$. The difference between applications and grants is significant $(\mathrm{p}<0.001)$ in favor of applications. Finally, a significant and positive difference with regard to the R\&D intensity of a national innovation system is observed; overall, more R\&D expenditures (per GDP) coincide with more stem cell-oriented technological activity.

Both legislative framework conditions under study significantly influence the amount of technological activity observed $(p<0.001)$. For countries with more permissive legislation - both with respect to obtaining human stem cells from supernumerary embryos and
R\&D on human therapeutic cloning-significantly more patent activity is observed, as can be seen by inspecting Table 5. Countries where the legislation explicitly allows obtaining human ESCs from supernumerary embryos display technological productivity figures $2.5 \times$ to $3 \times$ higher than countries constraining this type of research. Countries that permit $R \& D$ on human therapeutic cloning also show more technological productivity, although the difference is less pronounced (15\% to $20 \%)$. $^{20}$

Our analysis did not reveal a significant interaction between the two legislative conditions under study. Likewise, no differential effects of different types of stem cell research were observed, implying that the presence of both legislative frameworks affects technology development to a similar degree for all types of stem cells.

\footnotetext{
${ }^{20}$ Although these differences are to a large extent attributable to differences between countries (which did not change their legislation during the observed time period), within-country differences have been observed for a number of countries (e.g., Australia, Israel, Netherlands). Inspecting these cases in detail systematically reveals an increase in technological productivity when adopting a more permissive legislative stance.
} 
Table 5. Average Observed Patent Activity (Number PER Million Inhabitants) Under Different Legislative Frameworks

\begin{tabular}{lcc}
\hline & $\begin{array}{c}\text { Obtaining of } \\
\text { embryonic } \\
\text { stem cells from } \\
\text { supernumerary } \\
\text { embryos }\end{array}$ & $\begin{array}{c}\text { R\&D on } \\
\text { therapeutic } \\
\text { cloning }\end{array}$ \\
\hline Not allowed & 0.47 & 0.75 \\
Allowed & 1.46 & 0.90 \\
Vague/ambiguous & 0.65 & 0.85 \\
$\quad$ legislation & 0.82 & 0.82 \\
\hline
\end{tabular}

\section{CONCLUSION}

Promising advances in stem cell research have been accompanied by ethical concerns that have been translated differently in national regulations in various countries. In this analysis, we investigated whether legislative research frameworks affect the amount and nature of technological development activities within different national innovation systems. Our findings revealed that stem cell research legislation does affect technological activities in a significant manner. Countries with relatively flexible research legislation, such as Singapore, Taiwan, Spain, China, Belgium, UK, and Japan, display higher levels of technological activity (normalized by population). Research legislation, especially that which allows and defines the use of human stem cells harvested from supernumerary embryos, clearly influences the technological productivity of a particular territory. Overall, our findings suggest that technology trajectories are modulated by research legislation. ${ }^{21}$
${ }^{21}$ Rip A, Misa T, Schot J. Managing Technology in Society: The Approach of Constructive Technology Assessment. New York: Pinter Publishers, 1995; Vo $\beta$ J-P, Bauknecht D, Kemp R. Reflexive Governance for Sustainable Development. Cheltenham, UK: Edgar Elgar, 2006.

\section{APPENDIX 1: ANCOVA RESULTS: PATENTS/R\&D EXPENDITURES ACTING AS DEPENDENT VARIABLE}

The following table reports the findings obtained when using patent activity divided by R\&D expenditures as a dependent variable. Although the majority of the relations are in line with the findings reported in the body of the paper, the interaction between legislation pertaining to therapeutic cloning and type of stem cells becomes significant. In countries where therapeutic cloning is not allowed, higher levels of adult stem cell technological activity are observed; where therapeutic cloning is allowed, higher levels of embryonic stem cell research activity are being observed.

\begin{tabular}{|c|c|c|c|c|c|}
\hline Source & Type III sum of squares & $d f$ & Mean square & $F$ & $P$ value \\
\hline Corrected model & $26353.879^{\mathrm{a}}$ & 23 & 1145.821 & 5.495 & 0.000 \\
\hline Intercept & 5559.973 & 1 & 5559.973 & 26.665 & 0.000 \\
\hline Obtaining stem cells from supernumerary embryos allowed & 7218.614 & 2 & 3609.307 & 17.310 & 0.000 \\
\hline R\&D on therapeutic cloning allowed & 3494.421 & 2 & 1747.210 & 8.379 & 0.000 \\
\hline $\begin{array}{l}\text { Obtaining stem cells from supernumerary embryos allowed* } \\
\text { R\&D on therapeutic cloning allowed }\end{array}$ & 807.844 & 1 & 807.844 & 3.874 & 0.050 \\
\hline Type of stem cells & 3454.716 & 3 & 1151.572 & 5.523 & 0.001 \\
\hline Patent system (EPO/USPTO) & 262.994 & 1 & 262.994 & 1.261 & 0.262 \\
\hline Issued $(\mathrm{Y} / \mathrm{N})$ & 1052.723 & 1 & 1052.723 & 5.049 & 0.025 \\
\hline R\&D expenditures/GDP & 837.790 & 1 & 837.790 & 4.018 & 0.046 \\
\hline R\&D on therapeutic cloning allowed* type of stem cells & 6435.478 & 6 & 1072.580 & 5.144 & 0.000 \\
\hline $\begin{array}{l}\text { Obtaining stem cells from supernumerary } \\
\text { embryos allowed* type of stem cells }\end{array}$ & 1642.099 & 6 & 273.683 & 1.313 & 0.252 \\
\hline Error & 57132.144 & 274 & 208.511 & & \\
\hline Total & 128550.563 & 298 & & & \\
\hline Corrected total & 83486.023 & 297 & & & \\
\hline
\end{tabular}

${ }^{\mathrm{a}} \mathrm{R}^{2}=0.316$ (adjusted $\mathrm{R}^{2}=0.258$ ). 